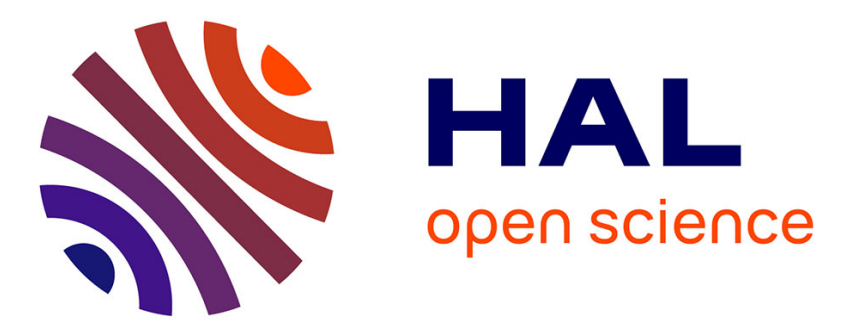

\title{
A Non-Intrusive Signal-Based Method for a Proton Exchange Membrane Fuel Cell Fault Diagnosis
}

Elodie Pahon, Nadia Steiner, Samir Jemei, Daniel Hissel, Philippe Moçoteguy

\section{To cite this version:}

Elodie Pahon, Nadia Steiner, Samir Jemei, Daniel Hissel, Philippe Moçoteguy. A Non-Intrusive SignalBased Method for a Proton Exchange Membrane Fuel Cell Fault Diagnosis. Fuel Cells, 2017, 17 (2), pp.238 - 246. hal-02131023

\section{HAL Id: hal-02131023 \\ https://hal.science/hal-02131023}

Submitted on 16 May 2019

HAL is a multi-disciplinary open access archive for the deposit and dissemination of scientific research documents, whether they are published or not. The documents may come from teaching and research institutions in France or abroad, or from public or private research centers.
L'archive ouverte pluridisciplinaire HAL, est destinée au dépôt et à la diffusion de documents scientifiques de niveau recherche, publiés ou non, émanant des établissements d'enseignement et de recherche français ou étrangers, des laboratoires publics ou privés. 


\section{A Non-Intrusive Signal-Based Method for a Proton Exchange Membrane Fuel Cell Fault Diagnosis}

E. Pahon ${ }^{1, *}$, N. Yousfi-Steiner ${ }^{2}$, S. Jemei ${ }^{1}$, D. Hissel ${ }^{1}$, P. Moçotéguy ${ }^{3}$

${ }^{1}$ FEMTO-ST UMR CNRS 6174, FCLAB Research Federation FR CNRS 3539, University of Bourgogne Franche-Comte, rue Ernest Thierry Mieg, 90010 Belfort Cedex, France

${ }^{2}$ LABEX ACTION CNRS, FEMTO-ST UMR CNRS 6174, FCLAB Research Federation FR CNRS 3539, University of Bourgogne Franche-Comte, rue Ernest Thierry Mieg, 90010

Belfort Cedex, France

${ }^{3}$ EIFER, European Institute for Energy Research, Emmy-Nother Strasse 11, 76131 Karlsruhe, Germany

[*]Corresponding author: elodie.pahon@univ-fcomte.fr 


\begin{abstract}
This paper presents an experimental study dealing with a non-intrusive signal-based method for a fault diagnosis of a Proton Exchange Membrane Fuel Cell (PEMFC). The aim of this tool is to define a specific signature of different operating conditions. First, a healthy state has to be defined: an operating condition with fixed parameters values for current, temperature, pressure is used as a reference state. When the operating conditions divert from this state of functioning, a fault is considered. Thanks to the wavelet transform of different signals from the fuel cell system, a signature can be extracted and linked to the considered operating conditions. The energy contents of the wavelet transform is used as an indicator of the State of Health (SoH) of the fuel cell system with the purpose to detect deviations from healthy state operating conditions and to detect the fault related to. The diagnosis tool presented in this paper is based on existing signals acquired on the fuel cell system, in order to minimize the number of actual sensors. The other goals are to minimize the number of extracted parameters from the fuel cell system and to be as less intrusive as possible in the fuel cell system.
\end{abstract}

Keywords: Diagnosis, Fuel cells, Hydrogen, Signal-based approach, Wavelet transform. 


\section{Introduction}

PEMFC is a promising technology for transport, with a new generation of electrical and/or hybrid vehicle applications [1], and stationary applications [2]. Improving PEMFCs' durability is considered as the most important challenge in its development for its possible large-scale commercialization [3]. The diagnosis tool aims at improving the fuel cell system lifetime by detecting some faults. To reach this aim, the diagnosis approach has to detect and identify some faults in order to avoid more serious faults. The detection phase is to be aware that there is a fault on the fuel cell system. The identification step is to determine the magnitude and the place where the fault appears. The diagnosis method also allows to develop some control strategies [4].

For PEM fuel cell fault diagnosis, many methods were tested for years. Basically, the diagnosis is divided into two kinds of approaches which are: model based [5] and non-model based [6]. The model-based approach consists in well-knowing all the physical behaviors to consider into a PEMFC. This electrochemical device is a multi-scale and a multi-physical tool that makes the modeling task difficult.

Buchholtz and al. proposed a nonlinear dynamic model obtained by system identification for PEMFC stacks. The static part representing the stationary points is separated from the dynamic part that described the deviation from these stationary points due to changes in the input signals. The static part is modelled thanks to a characteristic map and a neural network. For the dynamic part, transfer functions and a linear state-space model retrieved by canonical variate analysis are investigated [7]. The proposed method allows modelling the voltage per cell according to the current density, the stoichiometry of oxygen, the gas pressure and the relative humidity. Chevalier et al. [8] developed a pseudo 2D multiphysics AC and DC model coupled with electrochemical impedance spectroscopy to detect cells state-of-health in a PEMFC stack. This paper allows concluding that the flooding conditions for a stack lead a heterogeneous response of the system. König et al. present a model-aided system analysis tool 
in order to model different types of fuel cell systems [9]. The modeling approach includes the variable system model structure and the system component modeling: reformer and PEMFC. A detailed model based on the fuel cell theory and an empirical model is used. The aim of this model is to obtain information concerning the efficiency of the system and its individual system components, to reveal problems during operation. Le Ny et al. proposed a three dimensional electrical model of PEMFC stack [10]. The mathematical modeling allows taking into account the microscopic phenomena by averaging them over all the thickness of the membrane electrode assembly. The important role of water transport in the membrane on the transients is demonstrated thanks to a two-dimensional, transient, single-phase computational model by Serincan et al. [11]. The model is used to study the transient responses of the fuel cell system to changes in the cell voltage, pressure, and relative humidity of air for the cases of co-flow and counter-flow.

However, non-model based diagnosis methodologies exist. Zheng et al. [6] review three categories of them: the black box approach with the artificial intelligence [12], the statistical method by using Support Vector Machines (SVM) [13], for instance and the signal processing [14].

In [12], Kim et al. present a non-model based method able detecting the $\mathrm{SoH}$ of single cells. That allows the comparison with those of healthy and aged cells in experimental cell group. This method could also help selecting single cells with similar electrochemical specifications among the cells. Li et al. [13] aim implementing an online approach to diagnose a PEMFC. The method includes three stages: the data labeling, the training process and the diagnosis results. The algorithm allows detecting three $\mathrm{SoH}$ : normal state (without any fault, flooding fault mode and membrane drying state. Steiner et al. [15] describe a simple and low-cost flooding diagnosis method applied to a PEMFC. This method only uses the stack voltage and can be adapted to a large set of fuel cell configurations and applications. Coming from the signal-processing domain, the diagnosis consists in a signal feature extraction 
by multiscale decomposition using discrete wavelet transform, followed by fault identification and classification. Results obtained in this work showed that the wavelet analysis method allows the identification of the flooding based on the patterns obtained from the wavelet packet coefficients.

In [16], an empirical, intuitive, self-adaptive non-model based diagnosis method is developed. Voltage measurements are decomposed in fourteen Intrinsic Mode Functions in order to diagnose healthy, flooding and drying states. The diagnosis is performed without any excitation signal or stabilization period.

Gasperin et al. present in [17] an alternative computational method for on-line estimation and tracking of the impedance of PEM fuel cell systems. The method is developed in order to provide the information to diagnostics and health management system. The methods under consideration include continuous-time wavelet transform (CWT) and extended Kalman filter (EKF). The CWT is a time-frequency technique, which is suitable for tracking transient signal components. The EKF is a stochastic signal processing method, which provides confidence measures for the estimates. The paper shows, that both methods provide accurate estimates for diagnostics of FCS and can perform on-line tracking of these features. The performance of the algorithms is validated on experimental data from a commercial fuel cell stack.

In this paper, a signal-based method based on the wavelet transform, is used for the fault diagnosis task. According to different SoH of the fuel cell system, some trends and/or signatures can be found in order to feed the fault identification.

For this study, four operating conditions are reproduced on a test bench. Firstly, the PEMFC operates in the nominal operating conditions given by the manufacturer. Then, several high values of air stoichiometry are tested (up to 2). The method is developed to diagnose the whole fuel cell system therefore another considered fault is a heating problem. This fault can 
occur when the cooling system is broken. In this way, a study is done when the cooling system is stopped. Finally, the effects of an electrical short-circuit is analyzed too. They are the most common faults encountered on a PEMFC system. They are about the air feeding, the heating problems and the electrical devices ageing or breakage.

For all these operating conditions some signals are collected as voltage, current, power, pressure and so on, that are non-intrusive measurements. Based on these signals, the energy indicator is studied by analyzing: the energetic distribution for each details signal - after applying the wavelet transform - and the relative wavelet energy (RWE). The RWE is given according to a reference condition. It is a ratio between two energies corresponding to two different operating conditions.

From there, some trends and/or signatures appear according to the variations of these various parameters. Predictable behavior observed during an increasing or decreasing evolution of a criterion are called trends. As for signatures, it is characteristic representations and that it is possible to associate with defined or identified operating conditions. An energy distribution is given for a specific operating condition.

In the following sections, the diagnosis approach is described with the use of the wavelet transform and the extraction of indicators coming from the wavelet decomposition. The experimental tests used for the PEMFC diagnosis are then presented. Three kinds of faults are encountered during the operation of the system. Finally, some results of the applied approach are provided based on the energy indicator and according to the different faults tested.

\section{Diagnosis principle}

The non-intrusive signal-based method for a fault diagnosis [18] of a PEM fuel cell is here based on the wavelet analysis [15] and more precisely on the energy contents of the wavelet transform [19-20]. The wavelet energy is used as an indicator of the $\mathrm{SoH}$ of the fuel cell 
system, in the case of healthy or faulty modes (high air stoichiometry, cooling circuit fault and high current density).

\subsection{Wavelet decomposition}

The wavelet theory was developed in the late 1980s by Mallat [21] and Daubechies [22]. The basic principle of the wavelet decomposition consists in splitting a mother wavelet, which is a basis wavelet, into several approximations $A_{x}$ and details $D_{x}$. The approximation part is dedicated to the low frequencies and the detail part is related to the high frequencies of the input signal [14].

In this specific case, the wavelet decomposition method is the same as filtering the signal successively using a low-pass and a high-pass filter [23]. At each decomposition level, only the approximation is filtered in a new approximation and a new detail.

As an example, the figure 1a shows the basis wavelet decomposition chosen while the figure $1 \mathrm{~b}$ gives an example of decomposition of the stack voltage. A Daubechies 4 wavelet is chosen for its energy conservation properties and the decomposition level $j$ is defined according to Eq. (1) [24].

$$
j=\left\lfloor\frac{\log \left(\frac{f_{s}}{f_{c}}\right)}{\log (2)}-1\right\rfloor
$$

Where:

$f_{s}$ : sampling frequency of the input signal

\section{$f_{c}$ : frequency domain of the PEMFC}

L.]: the inferior integer part

About the frequency $f_{c}$ for the fuel cells, the frequency band is comprised between $\left[10^{-4} ; 10^{-2}\right]$ according to Refs. [24-25].

As for the numerical application, a PEMFC with a frequency $f_{c}=10^{-2} \mathrm{~Hz}$ is considered in this work. The sampling frequency of the input signal is $f_{s}=1 \mathrm{~Hz}$. 
Using Eq. (1), the optimal decomposition level is equal to 5.

Finally, the initial signal can be reconstructed thanks to the last approximation and the different details obtained. For instance on the figure 1a, the reconstruction of the initial signal is given by Eq. (2).

$$
s(t)=c A_{5}+c D_{5}+c D_{4}+c D_{3}+c D_{2}+c D_{1}
$$

\subsection{Relative Wavelet Energy (RWE)}

In the wavelet energy based method, the wavelet energy is calculated for each component of the signal therefore the energy distribution over the different frequency bands could be studied. This distribution can be treated as a representation of the information on the system process described by the studied signal [26].

For a detail $\boldsymbol{D}$ of the wavelet decomposition at level $j$, the energy $E_{j}^{d}$ can be computed by:

$E_{j}^{d}=\sum_{k}\left|C_{j}^{d}(k)\right|^{2}$

\section{Where $k$ is a sample.}

The total energy of the signal is calculated by Eq. (4).

$E_{\text {tot }}^{d}=\sum_{j} E_{j}^{d}$

The RWE is the ratio between a detail energy and the total energy obtained by summing the $j$ details energies of the signal (e.g. Eq. (5)).

$R W E=\frac{E_{j}^{d}}{E_{t o t}^{d}}$

The vector containing the percentages of energy, corresponding to the $j$ details, measures the strength of fluctuation of the original signal at the relevant frequency band. 


\section{Experimental application}

\subsection{Fuel cell technical description}

The experimental data are collected on a forty-cell stack $(3 \mathrm{kWe})$ manufactured by CEALITEN in France. Here, the stack is made of metallic gas bipolar plates. Table 1 summarizes some characteristics of the investigated fuel cell stack.

\subsection{Test bench description}

A $10 \mathrm{~kW}$ in-lab test bench is employed to fulfill the experimental requirements. The reactive gases are supplied through a humidification unit, respectively to the cathode and the anode. All cells of the stack are fed simultaneously. A cooling system keeps the stack temperature constant. Several parameters can be measured and controlled thanks to a National Instruments ${ }^{\mathrm{TM}}$ platform composed of different acquisition cards, as shown in table 2.

Based on this implementation, gas flows, reactant stoichiometry ratios, stack temperature, load current, inlet gas pressures and water cooling flow can be measured and controlled through the Labview ${ }^{\mathrm{TM}}$ software such as stack voltage and cell voltages. To sum up electric, fluidic, thermal and hydration states are controlled. The variety of recorded measurements on this in-lab test bench is interesting, especially for diagnosis, by allowing to study at each moment the variable behaviors.

\subsection{Description of the test protocol}

Some experimental tests are performed related to the air stoichiometry ratio. The nominal couple of stoichiometries (anode/cathode) are respectively (1.5/2). The variation on the air stoichiometry (FSC) range is $[1.1 \rightarrow 5]$. The increasing of the air stoichiometry $[2 \rightarrow 5]$ is here studied as a degraded state of health, which could result from a non-optimal control of the air compressor in an actual fuel cell system. 
Another problem is handled concerning the temperature regulation of the whole system. A fault in the cooling circuit is here emulated by stopping the cooling system during a minute. Firstly, the nominal water flow is reduced to its half value and finally completely stopped. During a short time, the operating temperature of the stack increases quickly and reached rapidly $100^{\circ} \mathrm{C}$ instead of $80^{\circ} \mathrm{C}$ (normal operating conditions). The figure 2 shows the evolutions of the stack voltage and the temperature before, after and while the fault occurs (without water cooling flow).

Another fault that has been tested on the fuel cell system concerns electrical faulty states. It is a real challenge to be able to diagnose this failure because it impacts a lot the fuel cell system. Here, a fault on the output power converter is considered (short-circuit). The appearance of this fault is mostly linked to the ageing of the electrical components, noises and disturbances, bad control or error on power switches. The first question is to know if the fuel cell system can support high currents and therefore related electrical short circuits. On the in-lab test bench, a fuse and a controllable circuit breaker are added to avoid irreversible damages on the PEM fuel cell. The duration of the short circuit is limited (about 10 seconds) to avoid strong thermal stress which can degrade irreversibly the fuel cell stack. More details about the electrical high current densities performed have been previously published in [27]. The impact of the failure is proportional to the current value. Figure 3 presents a pick of current density, ten times higher than the nominal current density of $0.5 \mathrm{~A} . \mathrm{cm}^{-2}$. The impact on the stack voltage and the temperature are also shown on the same figure. The fault and its impact on the system is maximal when the current density is maximal $\left(5 \mathrm{~A}^{\mathrm{c}} \mathrm{cm}^{-2}\right)$. According to [28-29] the different components can break after ageing and heating caused by high current as an electrical short circuit. A fusion point can also appear on the contact areas even the overload can remove a significant quantity of the material of the electrodes. 


\section{Results and Discussion}

\subsection{Algorithm}

The used method is based on the wavelet decomposition by using Daubechies wavelet [30] decomposition at level 5 (e.g. Eq. (1)). The signal used for the detection of failures is the air pressure drop (difference between inlet pressure and outlet pressure). This signal evolves when a fault appears on the stack. Firstly, the energy distribution under nominal conditions is given by using a sample of 10 minutes per operating mode. That gives one signature. Then, the operating conditions change. That implies a new signature according to the SoH. These signatures and the energetic trends of the 5 details, according to the different operating conditions, are studied here.

The algorithm is implemented on Matlab environment by using the wavelet decomposition and then the RWE based on the pressure drop recorded during experimental tests, for each kind of SoH. Finally, the energy contained in each details $\mathrm{D}_{1}, \mathrm{D}_{2}, \mathrm{D}_{3}, \mathrm{D}_{4}, \mathrm{D}_{5}$ is represented according to the healthy or faulty modes.

\subsection{Diagnosis results}

The figure 4 gives an example illustrating the result of a 5-level Daubechies wavelet on an air pressure drop signal. The sampling time for measuring this signal is $1 \mathrm{~s}$. The plot $c A_{5}$ is the approximation subsignal obtained at the final decomposition level, relevant to the frequency band of $0-1 / 32 \mathrm{~Hz}$. The curves $\left(c D_{5}\right.$ to $\left.c D_{1}\right)$ are the detail subsignals obtained at the 5-levels of decomposition. They illustrate fluctuating behaviors of the analysed signal at higher frequency bands. Figure 5 shows the frequency bands for each subsignals. The sampling frequency fs is equal to $1 \mathrm{~Hz}$ that gives 5 frequency bands: $\mathrm{D}_{1} \rightarrow[1 / 2,1] \mathrm{Hz} ; \mathrm{D}_{2} \rightarrow[1 / 4$, $1 / 2] \mathrm{Hz} ; \mathrm{D}_{3} \rightarrow[1 / 8,1 / 4] \mathrm{Hz} ; \mathrm{D}_{4} \rightarrow[1 / 16,1 / 8] \mathrm{Hz} ; \mathrm{D}_{5} \rightarrow[1 / 32,1 / 16] \mathrm{Hz}$ 
After the decomposition step, the relative wavelet energy is given, thanks to the wavelet toolbox of Matlab environment, and according to the three faults described in section 3.3. The figure 6 sums the results for the high air stoichiometry.

In the case of an air supplying due to a compressor failure for instance, the energetic distribution changes from the nominal operating conditions. When the air stoichiometry is equal to 2 (nominal), the detail $\mathrm{D}_{1}$ is the more energetic with a ratio of $35 \%$. When the air stoichiometry increases, the energy of $\mathrm{D}_{1}$ decreases and $\mathrm{D}_{5}$ becomes the more energetic detail. Two specific trends can be observed: the $\mathrm{D}_{1}$ trend and the $\mathrm{D}_{5}$ trend. The $\mathrm{D}_{1}$ trend decreases when the air stoichiometry increases and conversely.

The figure 7 gives the results for a cooling system fault. As previously fault, the PEMFC system works in the nominal operating conditions that gives an energetic distribution. Once again, $\mathrm{D}_{1}$ is the more energetic detail with $60 \%$ of RWE. When the cooling system is stopped, the energetic distribution changes and $\mathrm{D}_{5}$ has an energy of $65 \%$ compared to less than $10 \%$ for $\mathrm{D}_{1}$. After the fault occurrence, the system comes back to the nominal conditions and the energy of the detail $D_{5}$ decreases. The RWE of the detail D1 given doesn't return into the same healthy threshold than the initial value. The sample studied is just after the fault and a few minutes after returning to the nominal operating condition. In this way, we can observe the reversibility of the fault linked to a higher RWE of the detail D1 at this moment than at the initial phase. If a sample is chosen later, the RWE of the detail D1 should be lower than the last one. To sum up, the observation focused on the reversibility of the fault.

Thus, the exchange of the RWE between $\mathrm{D}_{1}$ and $\mathrm{D}_{5}$ when a fault occurs is again validated. 
The same remarks can be done on the figure 8 which represents the energetic distribution during an electrical short-circuit. The energetic trends of $\mathrm{D}_{1}$ and $\mathrm{D}_{5}$ are confirmed once again. According to the operating conditions the energy contents of the signal is different, especially for the first detail (circle). On the one hand, the RWE contained into the 1-level of the wavelet decomposition varies depending on the faulty operating conditions and on the other hand, the chronology of the details changes when the fault occurred. Some fault signatures can be proposed by using RWE on a signal recorded during several various operating conditions on a PEM fuel cell. For all the faults happening, the main energy content changes during a failure. The energy of the detail $D_{1}$ is bigger than others during the healthy mode while the detail $D_{5}$ is the more important during the fault occurrence. However, different ranges of energy can be observed. For instance, the relative wavelet energy for a high air stoichiometry is comprised between 30 and $40 \%$, between 60 and 70\% for cooling circuit fault and between 40 and 50\% for the electrical short-circuit. These ratios could be representative of the degree of severity of the fault. Moreover, the disparity between the 5 details is not the same according to the fault happening. The cooling circuit fault (figure 7) presents a large discrimination between the RWE of the major detail $\left(D_{5}\right)$ with regard to the four other details, contrary to the other kinds of fault (e.g. high air stoichiometry).

\section{Conclusion}

The SoH of the PEMFC is totally based on the experimental results without any need to model the fuel cell system. The signal observed is the air pressure drop between the inlet and the outlet of the stack therefore the method is a non-intrusive signal-based diagnosis approach. Depending on three faulty states, the algorithm can perform a significant signature during a fault occurrence. This signature is linked to the energetic distribution of the 5 details depending on the PEMFC SoH. In addition, two specific trends can be underlined for $\mathrm{D}_{1}$ and 
$\mathrm{D}_{5}$ details. There is an energy exchange between them as the system works in nominal operating conditions or in faulty mode. Moreover, the energetic distribution completely changes according to the $\mathrm{SoH}$. The computational cost is satisfied for a diagnosis approach with 0.15 second* to obtain the RWE results and trends compared to the studied fault time constraints (*Intel@ Core ${ }^{\mathrm{TM}}$ i7-3770 CPU @ 3.40GHz). As future work, some other signals like single-cell voltages or even stack voltage could also be considered, with the same signal-based diagnosis approach. Some other faults should be considered in order to improve this diagnosis tool ability.

\section{Acknowledgements}

The authors acknowledge French ANR project DIAPASON2 and also the Labex ACTION, ANR-11-LABX-01-01, for financially supporting these works and offering the possibility of using their data.

\section{References}

[1] M. Thoennes, A. Busse, L. Eckstein, Fuel Cells, 2014, vol. 14, issue 6, 781-791.

[2] P. Moçotéguy, B. Ludwig, J. Scholta, R. Barrera, S. Ginocchio, Fuel Cells, 2009, vol. 9, issue $4,325-348$.

[3] B.T. Huang, Y. Chatillon, C. Bonnet, F. Lapicque, S. Leclrec, M. Hinaje, S. Raël, Fuel Cells, 2012, vol. 12, issue 3, 335-346.

[4] S. Keller, A. Popenheim, M. Hempel, K. Gläsker, Y. Manoli, Fuel Cells, 2014, vol. 14, issue $5,758-768$.

[5] R. Petrone, Z. Zheng, D. Hissel, M.C. Péra, C. Pianese, M. Sorrentino et al. Int. J. Hydrogen Energy, 2013. 
[6] Z. Zheng. R. Petrone, M.C. Péra, D. Hissel, M. Becherif, C. Pianese, N. Yousfi Steiner, M. Sorrentino, Int J. Hydrogen Energy, 2013.

[7] M. Buchholz, V. Krebs, Fuel Cells, 2007, vol. 7, issue 5, 392-401.

[8] S.Chevalier, B. Auvity, J.C. Olivier, C. Josset, D. Trichet, M. Machmoum, Fuel Cells, 2014, vol. 14, issue 3, 416-429.

[9] ] P. König, A. Weber, N. Lewald, T. Aicher, L. Jörissen, E. Ivers-Tiffée, Fuel Cells, 2006, vol. 7 , issue $1,70-77$.

[10] M. Le Ny, O. Chadebec, G. Cauffet, J.M. Dedulle, Y. Bultel, Fuel Cells, 2012, vol.12, issue $2,225-238$.

[11] M.F. Serincan, S. Yesilyurt, Fuel Cells, 2007, vol. 7, issue 2, 118-127.

[12] J. Kim, I. Lee, Y. Tak, B.H. Cho, Int. J. Hydrogen Energy, 2012, 37, 5, 4280-4289.

[13] Z. Li, S. Giurgea, R. Outbib, D. Hissel, Fuel Cells, 2014, vol. 14, issue 3, 448-456

[14] E. Pahon, N. Yousfi-Steiner, S. Jemei, D.Hissel, P. Moçoteguy, Appl. Energy, 2016, vol. $165,748-758$.

[15] N. Yousfi Steiner, D. Hissel, P. Mocoteguy, D. Candusso, Int. J. Hydrogen Energy, 2011, 36, 740-746.

[16] C. Damour, M. Benne, B. Grondin-Perez, M. Bessafi, D. Hissel, .P. Chabriat, J. Power Sources, 2015, vol. 299, 596-603.

[17] M. Gašperin, P. Boškoski, A. Debenjak, J. Petrovčič, Fuel Cells, 2014, 457-465.

[18] R. Isermann, Fault-Diagnosis Systems: An introduction from Fault Detection to Fault Tolerance, Springer, 2005.

[19] N. Yousfi Steiner, D. Hissel, D. Candusso, P. Mocoteguy, L. Gautier, FR patent, FR 09 54357, 2009.

[20] N. Yousfi Steiner, K. Wang, M.C. Péra, D. Hissel, FR patent, FR 12 62319, 2012.

[21] S. Mallat, IEEE Trans. Pattern Anal. Mach. Intell., 1989, 11, 7, 674-693.

[22] I. Daubechies, IEEE Trans. Inf. Theory, 1990, 36, 5, 961-1005. 
[23] S. Mallat, A wavelet tour of signal processing, Elsevier, 1999.

[24] M. Ibrahim, S. Jemei, G. Wimmer, N. Yousfi-Steiner, C. C. Kokonendji, D. Hissel, Int. J. Hydrogen Energy, 2015, 1-11.

[25] K. Agbli, PhD Thesis, University of Franche-Comte, 2008.

[26] Z.K. Peng, F.L. Chu, Mechanical Systems and Signal Processing, 2004, 18, 199-221.

[27] R.E. Silva, F. Harel, S. Jemei, R. Gouriveau, D. Hissel, L. Boulon, K. Agbossou, Fuel Cells, 2014, vol. 14, issue 6, 894-905.

[28] C. Fox, Master's thesis, Virginia Polytechnic Institute and State University, USA, 2009.

[29] S. Wasterlain, D. Candusso, D. Hissel, F. Harel, P. Bergman, P. Menard, M. Anwar, J. of Power Sources 2010, 984 - 993.

[30] I. Daubechies. Ten lectures on wavelets. SIAM, 1992. 


\section{Figure Captions}

Figure 1a: Daubechies4 wavelet decomposition principle at level 5.

Figure 1b: example of the stack voltage decomposition (Daubechies4, 5 level decomposition)

Figure 2: Signal evolutions during cooling circuit fault.

Figure 3: Signal evolutions during electrical short circuit fault.

Figure 4: Daubechies4 wavelet decomposition at level 5 of the air pressure drop.

Figure 5: Frequency bands corresponding to the wavelet transform signal.

Figure 6: Relative Wavelet Energy for a high air stoichiometry fault.

Figure 7: Relative Wavelet Energy for a cooling system fault.

Figure 8: Relative wavelet Energy for an electrical short-circuit occurrence. 


\section{Table Captions}

Table 1: Technical specifications of the fuel cell used.

\begin{tabular}{ll}
\hline Characteristics & Values \\
\hline Number of cells & 40 \\
Cell area $/ \mathrm{cm}^{2}$ & 220 \\
Reactant stoichiometry ratio for both anode and cathode & Nominal : $1.5 / 2$ \\
Operating temperature $/{ }^{\circ} \mathrm{C}$ & 80 \\
Operating pressure $/ \mathrm{bar}$ & 1.5 abs \\
Operating current density / A.cm ${ }^{-2}$ & Nominal : 0.5 \\
Relative humidity for both anode and cathode $/ \%$ & $50 / 50$ \\
\hline
\end{tabular}

Table 2: Technical specifications of the fuel cell used.

\begin{tabular}{ll}
\hline Characteristics & Values \\
\hline Cooling system temperature $/{ }^{\circ} \mathrm{C}$ & {$[20-80]$} \\
Inlet gas temperatures $/{ }^{\circ} \mathrm{C}$ & {$[20-80]$} \\
Inlet gas humidifications $/ \%$ & {$[0-100]$} \\
Coolant flow rate $/ 1 . \mathrm{min}^{-1}$ & {$[0-20]$} \\
Air flow rate / Nl.min & \\
Hydrogen flow rate $/ \mathrm{Nl} . \mathrm{min}^{-1}$ & {$[0-500]$} \\
Gas pressures / bar & {$[0-100]$} \\
Current / A & {$[0-2.5]$} \\
\hline
\end{tabular}

